JOHN MILTON AND THE ENGLISH REVOLUTION 


\section{JOHN MILTON AND THE ENGLISH REVOLUTION}

A Study in the Sociology of Literature

Andrew Milner

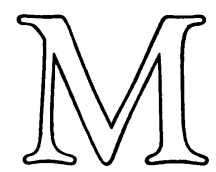




\section{For my parents Dorothy and John Milner}

(C) Andrew Milner I98 I

Softcover reprint of the hardcover 1st edition 1981

All rights reserved. No part of this publication may be reproduced or transmitted, in any form or by any means, without permission

First published 1981 by THE MACMILLAN PRESS LTD London and Basingstoke Companies and representatives throughout the world

First published in the USA 1981 by BARNES \& NOBLE BOOKS 81, Adams Drive Totowa, New Jersey, 07512

ISBN 978-1-349-04855-7 ISBN 978-1-349-04853-3 (eBook) DOI 10.1007/978-1-349-04853-3 


\section{Contents}

Acknowledgements vii

I Literature and Society: The Problem of Method I

I Marx's Sociology of the Forms of Consciousness 2

2 Goldmann's Genetic Structuralism 8

3 A Note on the Problem of Aesthetics 18

4 Lukács and Socialist Realism 24

5 Leavis and English Literary Criticism 38

6 Conclusion $\quad 46$

2 The World Vision of Revolutionary Independency so

3 The English Revolutionary Crisis 60

I The Nature of the Revolutionary Crisis 6I

2 Class and Class Conflict in the Revolutionary Period $\quad 74$

3 The Nature of Independency $\quad 84$

4 Reason Triumphant $\quad 94$

I The Discrete Rational Individual 97

2 Freedom from External Constraint $\quad 102$

3 Freedom from Passion 1 I 0

4 Milton's God $\quad$ I I 5

5 A Note on Milton's Epistemological and Aesthetic Principles $\quad$ I I 8

6 A Note on Comus

5 Reason Embattled $\quad$ I 38

I The Problem of Defeat: From Epic to Tragedy I 39

2 The Protestant Epic and the Spirit of Capitalism I 50

3 Paradise Regained $\quad 167$

4 Samson Agonistes $\quad$ I79 
6 A Note on Christopher Hill's Milton

195

I An Absent Presence: the Independents and the English Revolution

196

2 The Writer and Society 200

3 From Paradise Lost to Samson Agonistes 204

Notes

210

Bibliography

235

Index

243 


\section{Acknowledgements}

I would like to acknowledge the aid and assistance which I have received from Colin Barker, Ian Birchall, Verity Burgmann, Michael and Paul Crook, Geraldine Gillespie, Andrew Keogh, Professor David Martin, Richard Milner, Chris Sill, Colin Sparks, Kaye Stearman, Dr Alan Swingewood, Robert Tickner, Pam Townshend, Kathryn Wench, the staffs of the British Library of Political \& Economic Science and the University of London Library, and T. M. Farmiloe of the Macmillan Press. 